Ann. rheum. Dis. (1962), 21, 287.

\title{
COMPARISON BETWEEN THE LATEX NUCLEOPROTEIN TEST AND THE FLUORESCENT METHOD FOR THE DEMONSTRATION OF ANTINUCLEAR FACTOR
}

\author{
BY \\ R. BARNES \\ Department of Clinical Pathology, Guy's Hospital \\ D. CARMICHAEL \\ Department of Haematology, Guy's Hospital \\ AND \\ G. D. JOHNSON \\ M.R.C. Rheumatism Unit, Canadian Red Cross Memorial Hospital, Taplow, Berks
}

The evidence that systemic lupus erythematosus (S.L.E.) is a complex disease developing as a result of an auto-immune process is based on the finding in the serum of abnormal antibody-like globulins which can be shown to react with the patient's own blood cells and certain plasma constituents, and presumably result from the activity of immunologically-competent cells. Factors with affinity for nuclear antigens are prominent among the many abnormal proteins so far identified. Following the description of the L.E. cell by Hargraves, Richmond, and Morton (1948), the affinity of the patient's serum for nuclear components has been demonstrated by many workers, including Miescher (1957), who used the antiglobulin consumption method, Friou, Finch, and Detre $(1957,1958)$ and Holborow, Weir, and Johnson (1957), using the fluorescent antibody method, Ceppellini, Polli, and Celada (1957), by complement-fixation and precipitation, and Miescher and Strässle (1957), by the haemagglutination technique. These methods are more suitable for specialized laboratories on account of the technical difficulties involved, and therefore the description by Christian, Mendez-Bryan and Larson (1958) and Fessel (1959) of a simple latex precipitation method for the detection of antibodies to nucleoprotein indicated the possibility of a clinical test which could be carried out by routine laboratories.

A commercial preparation of nucleoproteincoated latex particles has now become available ("L.E. Test"), and the purpose of this communication is to report the results obtained by using this reagent compared with a routine fluorescent antibody method for the detection of antinuclear factor (A.N.F.).

\section{Materials and Methods}

(i) Sera.-These were obtained from 525 individuals. They had been submitted for the routine fluorescent A.N.F. test and included 24 cases of S.L.E., all of which satisfied the diagnostic criteria submitted by Bywaters and Ansell (1952) to the M.R.C. Collagen Panel (see Weir, Holborow, and Johnson, 1961, appendix). All specimens were stored at $-20^{\circ} \mathrm{C}$.

(ii) Fluorescent Antibody Technique.-The method used has been fully described by Weir and others (1961). Cryostat sections of human or bovine thyroid were treated with the test serum at $37^{\circ} \mathrm{C}$., washed and subsequently stained with rabbit anti-human globulin, conjugated with either fluorescein isocyanate or isothiocyanate. Under ultra-violet microscopy the presence of antinuclear factor is revealed by nuclear immunofluorescence.

The results of this test were assessed subjectively as positive $(+)$, negative $(-)$, or doubtful weak positive $( \pm)$.

(iii) Latex Nucleoprotein Test.-The "L.E. Test" reagent contained polystyrene particles with an average diameter of $0.25 \mu(0 \cdot 15 \mu-0.35 \mu)$. Nucleoprotein, prepared in hypertonic solution from calf thymus by the method of Mirsky and Pollister (1946), was precipitated on the latex particles.

The sensitized latex nucleoprotein reagent was supplied with a standardized dropper. One drop of the reagent was mixed with one drop of patient's serum on a meniscoid glass slide of standard area. The reaction took place with gentle agitation for exactly 2 minutes and in order 
to standardize the procedure use was made of a mechanically-operated black tiled rocking-box heated to $37^{\circ} \mathrm{C}$. Any degree of macroscopic agglutination after 2 minutes was considered positive; in negative tests the suspension remained homogeneous.

(iv) DNA Estimations. - These were performed by the method described by Dische (1930). This consists of mixing $2 \mathrm{ml}$. fresh diphenylamine reagent $(1 \mathrm{~g}$. diphenylamine dissolved in $100 \mathrm{ml}$. glacial acetic acid and $2.75 \mathrm{ml}$. concentrated sulphuric acid) with $1 \mathrm{ml}$. of the solution under test. After heating at $100^{\circ} \mathrm{C}$. for 10 minutes, the resulting blue colour is compared at $600 \mathrm{~m} \mu$, with the colour obtained from a standard solution of highly polymerized calf thymus DNA.

\section{Results}

The total number of sera tested independently by both the fluorescent antibody and the latex nucleoprotein methods was 525 , excluding duplicated specimens and the positive and negative control sera that were used to test each bottle of latex nucleoprotein reagent. The results are shown in Table I.

TABLE I

COMPARISON OF LATEX NUCLEOPROTEIN TEST AND FLUORESCENT ANTINUCLEAR FACTOR IN 525 INDIVIDUALS

\begin{tabular}{|c|c|c|c|c|c|}
\hline \multirow[b]{2}{*}{ Test } & \multirow{2}{*}{\multicolumn{2}{|c|}{ Agreement }} & \multicolumn{3}{|c|}{ Disagreement } \\
\hline & & & \multicolumn{2}{|c|}{$\begin{array}{c}\text { Latex } \\
\text { False } \\
\text { Positive }\end{array}$} & \multirow{2}{*}{$\begin{array}{c}\begin{array}{c}\text { Latex } \\
\text { False } \\
\text { Negative }\end{array} \\
-\end{array}$} \\
\hline Latex Nucleoprotein & - & + & + & + & \\
\hline $\begin{array}{l}\text { Fluorescent Antinuclear } \\
\text { Factor } \ldots\end{array}$ & - or \pm & + & - & \pm & + \\
\hline Total & 470 & 8 & 6 & 1 & 40 \\
\hline
\end{tabular}

It will be seen that 478 sera showed agreement in both tests. These included 470 which were negative and eight which were positive by both procedures.

The cases in which the results of the two methods did not correspond are interesting. There are two main groups: the group which although negative in the fluorescent antibody test gave a positive result with the latex nucleoprotein test, and the group which although negative with the latex reagent showed positive immuno-fluorescence.

The seven sera which were positive in the latex test and negative by the fluorescent technique included five which were subsequently shown to be infected, one serum from a relative of a patient with undefined "collagen disease", and one from a case of discoid lupus erythematosus. These last two results remain unexplained although both tests have been repeated on several occasions on the same sample confirming the original findings. In view of the result obtained with the five infected sera, it was decided to determine the effect of infection on the latex nucleoprotein test using normal sera.

75 normal sera which had been found to be negative in the latex nucleoprotein test were infected with a mixed culture of Proteus vulgaris and Escherichia coli and incubated at room temperature for 24 hours. Subsequent re-testing of the specimens with the same "L.E.-Test" reagent showed that twelve sera had become positive giving obvious macroscopic agglutination. Although four of these specimens showed very coarse atypical agglutination, eight showed a positive result that was indistinguishable from a standard latex nucleoprotein positive test (Figure, opposite). Further testing of the infected false positive specimens, using the supernate after centrifuging at 3,000 r.p.m. for 5 minutes, yielded negative results in each case. Four positive control sera that were also deliberately infected remained positive after being infected with the mixed culture and incubated; subsequent testing of the supernate after centrifugation still gave a positive agglutination reaction.

The analysis of the cases in which the lateg nucleoprotein test was negative and the fluorescer test positive is shown in Table II. It can be sees that there were sixteen cases of defined S.L.E., all of which satisfied the diagnostic criteria referred to above, and 24 sera from miscellaneous and undiagnosed disorders. These latter included four cases in which a diagnosis of S.L.E. could not be excluded.

\section{TABLE II}

DIAGNOSIS IN CASES WITH FLUORESCENT ANTINUCLEAR FACTOR POSITIVE BUT LATEX NUCLEOPROTEIN TEST NEGATIVE

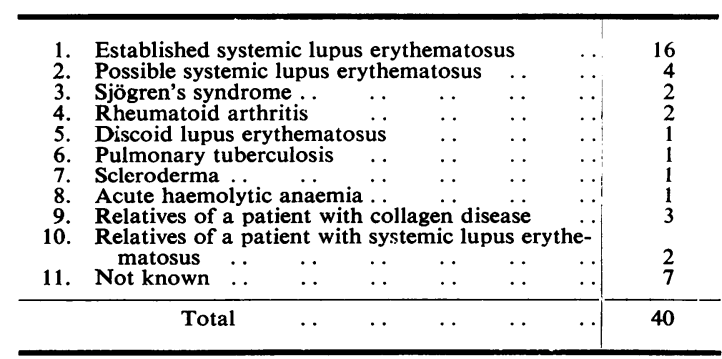

The possibility that the failure of the "L.E. Test" to give a positive reaction with some of the fluorescent-positive S.L.E. sera might be accounted for by the presence of free (inhibiting) DNA in solution in the latex reagent was investigated as described in the following experiments. 
The amount of DNA in the supernate after

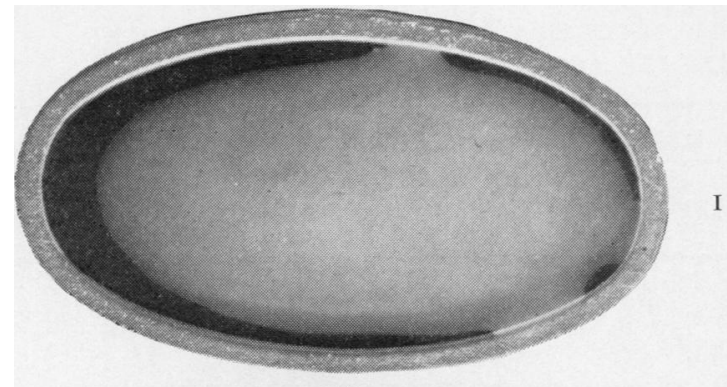
centrifuging the reagent at 10,000 r.p.m. for 10 minutes was estimated by the Dische reaction and found to be $385 \gamma / \mathrm{ml}$. In view of this finding it was decided to compare the reaction obtained with fluorescent positive sera and untreated "L.E.Test" reagent with the reaction obtained using latex reagent in which the supernate had been replaced by an equal volume of standard McIllvaine's buffer at $\mathrm{pH} 6 \cdot 0$. Serum titrations were performed using this buffer solution as a diluent against the original latex reagent and the reagent from which free DNA-containing supernate had been removed and replaced by buffer solution. With one serum, the results (Table III, overleaf) showed that the supernate did have some inhibitory effect upon the reaction.

However, on testing fifteen further fluorescentpositive S.L.E. sera with both the original and the reconstituted latex reagent, the results were obtained that are shown in Table IV (overleaf), from which it is evident that removal of the free DNA from the latex nucleoprotein reagent did not enhance the sensitivity of the test. Furthermore, it was found that the supernate from the latex nucleoprotein reagent failed to inhibit the staining obtained with four sera tested by the fluorescent procedure after dilution of the sera with the DNA-containing solution instead of with saline.

\section{Discussion}

In view of the technical difficulties involved in the Coon's indirect fluorescent antibody method for the detection of antinuclear factor, an alternative test based on a simple slide agglutination reaction using nucleoprotein-coated latex particles would appear to possess obvious advantages. However, it is apparent that simplicity has been gained at the expense of sensitivity. Only eight out of 24 clinically-defined S.L.E. sera, all of which had been found to be positive by the fluorescent technique, were detected by the latex method.

FIGURE.-Latex nucleoprotein reaction after $2 \mathrm{~min}$. gentle agitation at $37^{\circ} \mathrm{C}$.

I Non-infected normal serum. Negative reaction.

II Non-infected serum from a case of systemic lupus erythematosus. Positive reaction.

III Infected normal serum (I). False positive reaction.

IV Infected normal serum. False positive reaction with atypical agglutination.

V Infected normal serum (IV). Negative reaction after centrifugation. 
TABLE III

TITRATION OF SYSTEMIC LUP' 'S ERYTHEMATOSUS SERUM TESTED WITH ORIGINAL LATEX REAGENT AND LATEX REAGENT WITH SUPERNATANT REPLACED BY AN INERT BUFFER

\begin{tabular}{|c|c|c|c|c|c|c|c|c|c|c|c|c|c|c|c|}
\hline Serum Dilutions . & . & . & $1: 1$ & $1: 2$ & $1: 4$ & $1: 8$ & $1: 16$ & $1: 32$ & $1: 64$ & $1: 128$ & $1: 256$ & $1: 512$ & $1: 1024$ & $1: 2048$ & $1: 4096$ \\
\hline \multirow{2}{*}{$\begin{array}{c}\text { Latex } \\
\text { Nucleoprotein } \\
\text { Reagent }\end{array}$} & \multicolumn{2}{|c|}{ Original } & + & + & + & + & + & + & + & - & - & - & - & - & - \\
\hline & \multicolumn{2}{|c|}{ Reconstitated } & + & + & + & + & + & + & + & + & + & + & - & - & - \\
\hline
\end{tabular}

TABLE IV

FIFTEEN SYSTEMIC LUPUS ERYTHEMATOSUS SERA (ALL POSITIVE TO FLUORESCENT A.N.F.) TESTED WITH ORIGINAL LATEX NUCLEOPROTEIN REAGENT AND LATEX REAGENT WITH SUPERNATANT REPLACED BY AN INERT BUFFER

\begin{tabular}{|c|c|c|c|c|c|c|c|c|c|c|c|c|c|c|c|c|}
\hline Serum No. & . & 1 & 2 & 3 & 4 & 5 & 6 & 7 & 8 & 9 & 10 & 11 & 12 & 13 & 14 & 15 \\
\hline \multirow{2}{*}{$\begin{array}{c}\text { Latex } \\
\text { Nucleoprotein } \\
\text { Reagent }\end{array}$} & Original & - & + & - & - & - & + & + & - & - & - & - & + & - & - & - \\
\hline & Reconstituted & - & - & - & - & - & + & - & - & - & - & - & + & - & - & - \\
\hline
\end{tabular}

The inhibitory action of DNA and nucleoprotein upon the other serological tests for S.L.E. has been shown by Holman and Kunkel (1957) and Hijmans and Schuit (1958), and therefore the finding of $385 \gamma$ of DNA per ml. in the supernate of the reagent suggested that false negative tests might be the result of specific inhibition. However, further studies have shown that this does not account for all the false negative findings, and the reasons for the apparent hyposensitivity of the latex-nucleoprotein test must therefore remain open to speculation. Although in this survey we have compared the latex nucleoprotein test only with the fluorescent antibody method, Dubois, Drexler, and Arterberry (1961) have recently published their findings comparing the "L.E. Test" with the demonstration of L.E. cells in the peripheral blood. It is interesting to note that the comparison between these two techniques showed that only 31 per cent. of the specimens in which L.E. cells were demonstrated gave a positive latex nucleoprotein test. Although no diagnostic criteria were stated in respect of their cases of S.L.E., the comparative sensitivity of the latex nucleoprotein reagent with regard to the L.E.-cell phenomenon is very similar to our comparison between the latex nucleoprotein test and the fluorescent method (33 per cent.).

It has been found that infected sera can give false positive latex reactions which are often indistinguishable from the reaction given by S.L.E. sera, and that this non-specific agglutination can be prevented by carrying out the test on the supernate after centrifugation. On the other hand, the supernate from true latex positive S.L.E. sera after artificial infection is still capable of giving a positive reaction.

The difference we have found between the results obtained by the fluorescent antibody test for antinuclear factor and the nucleoprotein latex methog $\overrightarrow{\mathscr{O}}$ suggests that, whereas the fluorescent techniqt detects serum factors against one or more of the nuclear fractions and even the nucleus in toto, the latex nucleoprotein reagent is probably only detecting "antibodies" to certain soluble nuclear derivatives that form the coating of the latex $\mathbb{D}$ particles. In this respect the fluorescent technique $\underset{\vec{P}}{\overrightarrow{2}}$ may be considered to cover the whole spectrum $\frac{0}{3}$ of anti-nuclear factors, the latex nucleoprotein $\frac{3}{5}$ reagent only covering a small, yet defined, segment of this spectrum.

\section{Summary}

A comparative study of the results obtained by the fluorescent antibody method for the detection 8 of serum anti-nuclear factor and a commercially available latex nucleoprotein reagent ("L.E. Test") 윽 has been carried out on a series of 525 sera.

The latex nucleoprotein test was positive in only eight out of 24 cases of clinically-defined systemic lupus erythematosus, in all of which the fluorescent 0 test was positive. Infected sera were found to be $N$ responsible for five false positive latex nucleo- N protein reactions; however, after centrifugation anc subsequent testing of the supernate, these sera became negative. The exclusion of the false positiv reaction by centrifugation did not interfere with thi $\stackrel{?}{?}$ genuine latex positive reaction.

The latex nucleoprotein test was positive, atic 
infection of the serum had been excluded, in two individuals in whom the fluorescence test was negative - a case of discoid lupus, and a relative of a patient with an undefined collagen disease.

To account for the relative hyposensitivity of the latex nucleoprotein reaction, we have considered the possibility of inhibition by free DNA, which we have shown to be present in the latex reagent. When coated particles resuspended in DNA free buffer were substituted in the test, however, no significant increase in sensitivity was found. It does not therefore appear that this test is a satisfactory substitute for the immuno-fluorescent procedure in the detection of serum antinuclear factor.

We are very grateful to Dr. E. J. Holborow for his advice and encouragement, to Dr. W. Hijmans for some of the S.L.E. sera, and to Baxter Laboratories Ltd. for supplying the "L.E.-Test" reagent.

\section{REFERENCES}

Ceppellini, R., Polli, E., and Celada, F. (1957). Proc. Soc. exp. Biol. (N.Y.), 96, 572.

Christian, C. L., Mendez-Bryan, R., and Larson, D. L. (1958). Ibid., 98, 820.

Dische, Z. (1930). Mikrochemie, 8, 4.

Dubois, E. L., Drexler, E., and Arterberry, J. D. (1961). J. Amer. med. Ass., 177, 141.

Fessel, W. J. (1959). Ann. rheum. Dis., 18, 255.

Friou, G. J., Finch, S. C., and Detre, K. D. (1957). Fed. Proc., 16, 413.

,,$---(1958) . \quad$ J. Immunol., 80, 324.

Hargraves, M. M., Richmond, H., and Morton, R. (1948). Proc. Mayo Clin., 23, 25.

Hijmans, W., and Schuit, H. R. E. (1958). Vox. Sang. (Basel), 3, 184.

Holborow, E. J., Weir, D. M., and Johnson, G. D. (1957). Brit. med. J., 2, 732.

Holman, H. R., and Kunkel, H. G. (1957). Science, 126, 162.

Miescher, P. (1957). Hautarzt, 8, 502. and Strässle, R. (1957). Vox. Sang. (Basel), 2, 283.

Mirsky, A. E., and Pollister, A. W. (1946). J. gen. physiol., 30, 117.

Weir, D. M., Holborow, E. J., and Johnson, G. D. (1961). Brit. med. J., 1, 933.

Comparaison entre la réaction de la nucléoprotéine sur latex et la méthode de fluorescence pour déceler le facteur antinucléaire

\section{RÉSUMÉ}

Sur une série de 525 sérums on compara les résultats obtenus par la méthode de l'anticorps fluorescent et ceux obtenus en usant un réactif commercial ("L.E. Test"), composé de latex enduit d'une nucléoprotéine, ur déceler le facteur antinucléaire.
La réaction de la nucléoprotéine sur latex fut positive seulement dans 8 sur 29 cas de lupus érythémateux disséminé, confirmé en clinique, tandis que le test de fluorescence fut posıtif dans tous les cas. Des sérums infectés furent trouvés responsables de cinq fausses réactions positives de la nucléoprotéine sur latex; toutefois, après la centrifugation et l'analyse du liquide surnageant, tous ces sérums devinrent négatifs. L'exclusion de faux résultats positifs par centrifugation ne dérangeait pas les réactions réellement positives au latex.

La réaction de la nucléoprotéine sur latex fut positive, après l'exclusion de l'infection du sérum, chez deux sujets chez qui le test de fluorescence fut négatif-un cas de lupus discoïde et un parent d'un malade atteint d'une maladie mal définie du collagène.

Pour expliquer la relative hypersensibilité de la réaction de la nucléoprotéine sur latex, nous avons considéré la possibilité de l'inhibition par l'acide desoxyribonucléique (DNA) libre, trouvé par nous dans le réactif au latex. Toutefois, après avoir suspendu de nouveau les particules enduites d'antigène dans un milieu tamponné ne contenant pas de DNA libre, nous n'avons pas trouvé de sensibilité appréciablement augmentée. Il ne semble donc pas que cette réaction puisse remplacer avantageusement le procédé d'immuno-fluorescence pour déceler le facteur antinucléaire.

Comparación entre la reacción de nucleoproteina sobre latex y el método de fluorescencia para la demostración del factor antinuclear

\section{Sumario}

Se efectuó sobre una serie de 525 sueros un estudio comparativo de los resultados obtenidos por el método del anticuerpo fluorescente y por el empleo de un reactivo comercial de nucleoproteina sobre latex ("L.E.-Test") con el fin de evidenciar el factor antinuclear.

La reacción de la nucleoproteina sobre latex fué positiva en sólo ocho de 29 casos de lupus eritematoso diseminado clínicamente confirmado, en todos los cuales el test de fluorescencia fué positivo. Suero infectado se encontró responsable de cinco falsas positividades de las reactiones de nucleoproteina sobre latex; sin embargo, después de centrifugación y subsecuente análisis del líquido sobrenadante, estos sueros se volvieron negativos. La exclusión de la falsa reacción positiva por centrifugación no interfiere con la auténtica reacción positiva sobre latex.

La reacción de nucleoproteina sobre latex fué positiva, después de exluir una infección del suero, en dos sujetos en los que el test de fluorescencia fué negativo-un caso de lupus discoide y un familiar de un paciente con una enfermedad indefinida del colágeno.

Para explicar la relativa hipersensibilidad de la reacción de nucleoproteina sobre latex, hemos considerado la posibilidad de inhibición por el ácido deoxiribonucléico (DNA) libre, cuya presencia fué encontrada por nosotros en el reactivo con latex. Sin embargo, cuando se resuspendieron las partículas recubiertas de antígeno en un medio taponado sin DNA libre, no se encontró aumento apreciable de la sensibilidad. Por lo tanto no parece que esta reacción es un substituto satisfactorio del proceder inmuno fluorescente en la detección del factor antinuclear del suero. 